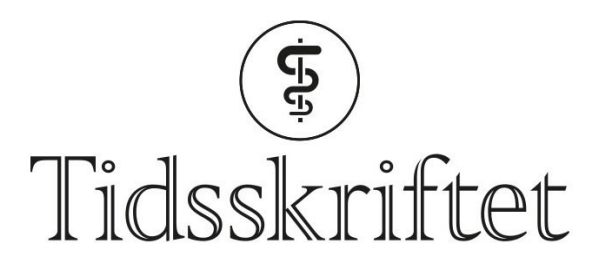

DEN NORSKE LEGEFORENING

\title{
Forside nr. 18/2019
}

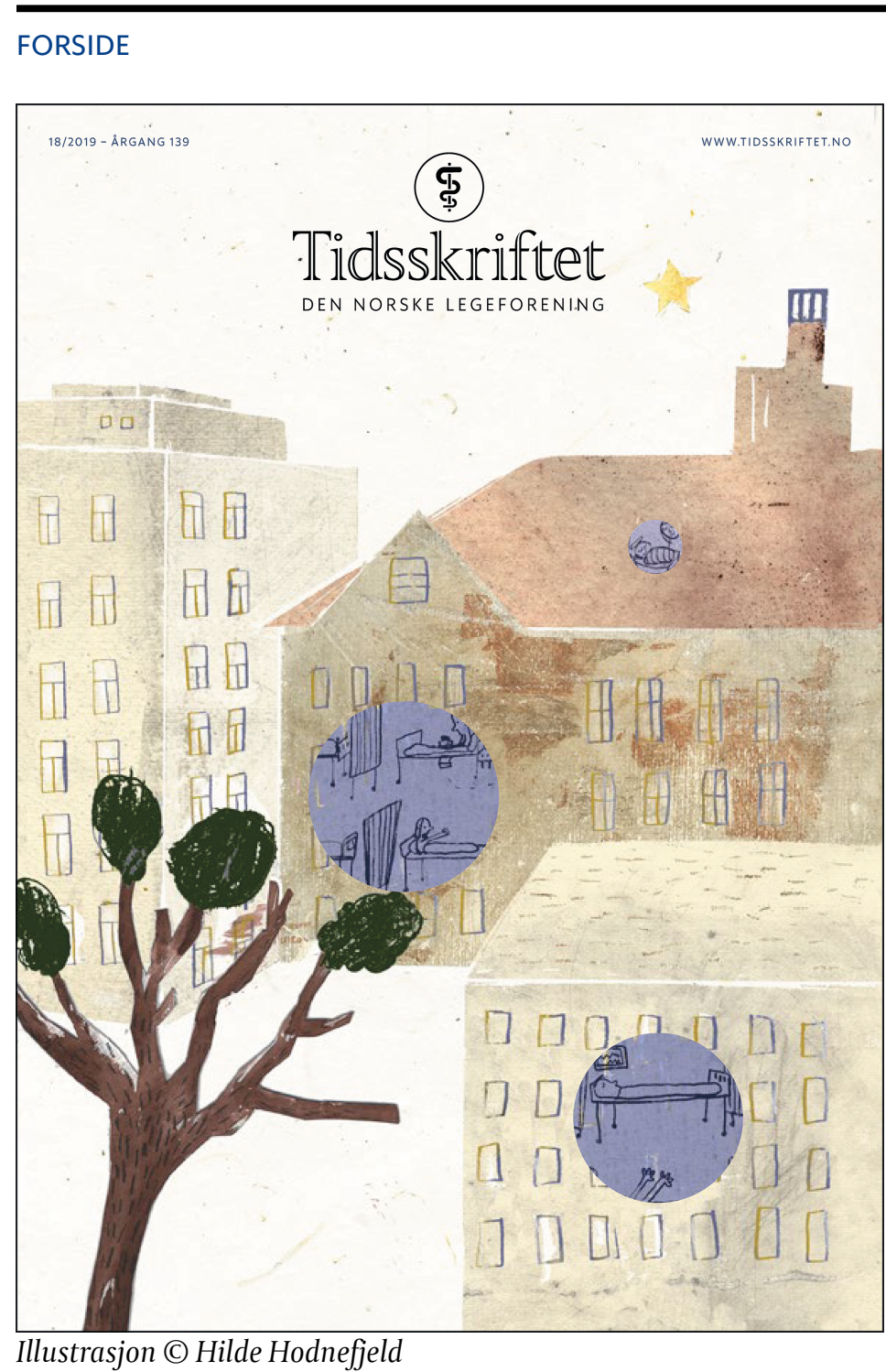

Kortere liggetider, flere pasienter, mer poliklinikk, mer dagbehandling, mer rapportering, flere møter, flere administrative oppgaver. Alle som har vært helsearbeidere en stund kjenner det på kroppen: Hverdagen har blitt travlere. Effektivitet er tidens melodi. Ledige ressurser skal utnyttes maksimalt. Men et sted går det en grense, der mye å gjøre blir FOR mye å gjøre. Da blir travelhet til stress, effektiviteten synker og både pasientbehandling og helsearbeidere lider. Herberget er fullt. Men nettopp da er det viktig å stoppe opp ved undrene som hver dag skjer i helsevesenet, selve grunnen til at vi er der: de magiske menneskemøtene der håp blir tent.

Det er illustratøren Hilde Hodnefjeld som har tegnet forsiden denne gangen. Flere av 
hennes arbeider finner du her: $h t t p: / / w w w . h o d n e f j e l d . n o /$

Publisert: 9. desember 2019. Tidsskr Nor Legeforen. DOI: 10.4045/tidsskr.19.18.02

(C) Tidsskrift for Den norske legeforening 2020. Lastet ned fra tidsskriftet.no 